\title{
Responses to Ethical Violations by Female Sports Leaders: A Relational Approach
}

\author{
Audrey J Murrell* and Ray Jones \\ Professor of Business Administration, USA
}

ISSN: 2639-0612

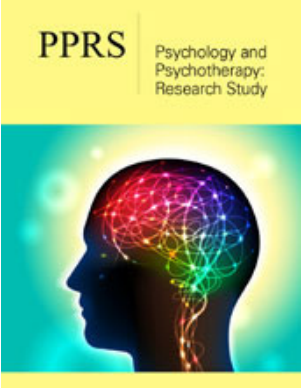

*Corresponding author: Audrey J Murrell, Professor of Business Administration, USA

Submission: 眥 December 11, 2019

Published: 制December 18, 2019

Volume 3 - Issue 2

How to cite this article: Audrey J Murrell,Ray J. Responses to Ethical Violations by Female Sports Leaders: A Relational Approach. Psychol Psychother Res Stud. 3(2).PPRS.000560.2019.

DOI: 10.31031/PPRS.2019.03.000560

Copyright@ Audrey J Murrell, This article is distributed under the terms of the Creative Commons Attribution 4.0 International License, which permits unrestricted use and redistribution provided that the original author and source are credited.

\begin{abstract}
Using Rusbult's investment typology of exit, voice, loyalty and neglect response categories [1], we employ a relational approach to understand how contextual and situational factors influence female athletic leaders' responses to ethical violations. Specifically, we examine blatant versus subtle violations (situational) versus rule-based and gender-based violations (contextual) factors. We find that female athletic leaders elected constructive (voice, loyalty) responses more frequently when violations were blatant or destructive (exit, neglect) responses were selected more frequently when violations were subtle. Violations that were gender-based versus rule-based elicited more destructive (exit, neglect) responses. Implications for how to increase leaders' effectiveness and the role of gender in responses to ethical violations are discussed.
\end{abstract}

Keywords: Rule violations; Gender; Ethical responses; Ethical attitudes; Sports; Leadership

\section{Introduction}

Organizations have constantly faced issues related to ethics and rule violations. While carrying out their everyday tasks and roles, leaders have to deal with issues such as interpreting formal rules, following code of ethics, as well as actions that my interfere with achieving organizational objectives. Research shows that individuals make ethical decisions based on their personal moral values and other influences such as standards set by an organization, assessment of consequences of their actions and an appraisal of their responsibilities [2-4]. When faced with rule violations, individuals constantly struggle to strike a balance between their personal moral values or towards the codes of conduct set by their organizations [57]. In our study, we examine female leaders within collegiate sports organizations and their responses to ethical rule violations.

Using a sports context, we examine the influence of situational and contextual factors on responses to ethical violations. In addition, we use Rusbult's [1] typology of exit, voice, loyalty and neglect responses, to understand how relational factors influence female athletic administrators' responses to ethical violations $[1,8]$. This paper contributes to the literature on responses to ethical violations in two important ways. Theoretical models of the ethical decision-making process conceptualize responses to ethical violations as a function of various individual and organizational attributes. The first contribution of our paper is to include the impact of both situational and contextual factors on responses to ethical violations. Specifically, we examine the severity of violations as a situational factor (blatant versus subtle) and the whether the violation is rule-based or gender-based as a contextual factor. The second contribution of our paper is that we define responses to ethical violations from relational perspective using the investment framework developed by Rusbult and colleagues [1]. Despite the fact that current models of ethical decision making are reasonably comprehensive; these models are limited in understanding the different ways that individuals choose to respond to an ethical violation from a relational perspective. The investment framework provides a unique lens to examine under what conditions individuals will elicit more constructive responses versus destructive responses to ethical violations. Our research examines responses to ethical violations based on this relational perspective among female leaders within a collegiate sports setting. 


\section{Responses ethical rule violations}

Researchers have viewed the problem of rule violations through different theoretical frameworks [9]. From a gamesmanship perspective, rule violations occur when there is more emphasis on winning rather than performing at the highest level [10]. A dispositional framework suggests that individuals have differing levels of moral reasoning and therefore some individuals engage in rule violations while others do not $[11,12]$. Researchers have extended the organizational justice framework to examine rule violations in college athletics, specifically the role of distributive, interactive, and retributive justice [13]. Finally, rule violations have also been examined from an economic cost benefit analysis framework [14] which suggests that cheating will occur when the benefits of cheating outweigh the costs. Conversely, cheating will cease to occur when the costs outweigh the benefits.

These different theoretical frameworks have predominantly focused on cognitive aspects to assess ethical rule violations and have largely ignored the role of relational factors. We argue that it is important to view ethical violations from a relational perspective as individuals are closely tied to their surrounding situation and context when they are faced with ethical dilemmas. Using Rusbult's typology of exit, voice, neglect and loyalty [1], we employ a relational approach to capture individuals' responses to ethical violations. Before we apply a relational framework to outline how individuals respond to ethical violations, we briefly examine the key models of ethical decision making. Researchers have contributed to the field of ethical decision making by conceptualizing a number of theoretical models [15-17]. These various ethical decisionmaking models suggest an interactionist approach, where ethical decision making is a function of various individual, situational and contextual factors. For example, the model provided by Rest [16] views ethical decision-making as involving four basic steps identifying the ethical nature of an issue, ethical a moral judgment, establishing ethical intent, and engaging in ethical action. Jones's [15] made significant contributions by synthesizing previous psychological models of ethical decision making and proposing an issue-contingent model of ethical decision making. His model of ethical decision making includes six issue characteristics that affect the perceived moral intensity of an ethical dilemma: personal perceptions of the magnitude of consequences, social consensus, proximity, probability of effect, temporal immediacy, and concentration of effect. These characteristics of moral intensity affect individual ethical decision making in all the four stages of the model proposed by Rest [16]. The interactionist model focuses on individual level factors such as cognitive biases, affect, and identity, as well as organizational factors, such as ethical climate and workrelatedness [18]. Overall these various models for ethical decisionmaking can be extended to help us better understand individual's responses to violations of ethical codes and organizational rules.

\section{Situational factors that impact responses to ethical violations}

Substantial prior research studies examine the role of individual influences on ethical decision making [18-20]. Individual factors include gender, education, years of experience, age, value orientation, cognitive moral development, emotion, and locus of control. The effects of these individual difference variables on unethical behaviors have been studied extensively. For example, women have obtained higher scores on rating ethical scenarios [21]; senior students are less ethical than junior students [22]; age has a negative effect on ethical attitude [23]; individuals in the latter years of their career display higher ethical judgment [24]; Machiavellianism is negatively associated with ethical decision making [25,26]; and locus of control is negatively associated with ethical standards [27]. Kennedy \& Kray [28] specifically examined gender differences in reaction to ethical compromises and find women react more negatively than men to decisions that subordinate their ethical values of honesty and fairness. These empirical studies highlight the importance of individual influences on ethical decision-making. However, individual factors are not the only influences on ethical decision making and responses to ethical violations. Situational factors include codes of ethics, industry type, organizational size, rewards and sanctions, organizational pressures, and leadership behaviors. Other research studies examine contextual factors such as the influence of climate or culture on ethical decision-making and responses [29-30].

This includes research on factors such as corporate culture [5,31,32] and commitment to ethical codes [33]. For example, in her model of ethical decision making, Trevino emphasized the importance of social context and how moral action can be greatly influenced by situational factors [17]. Thus, in the current research we include both situational and contextual factors in order to better understand responses to ethical violations. However, in order to understand the impact of situational factors, we must first examine different perspectives of the role that situational factors play in ethical decision making especially where the consequences of individual decisions affect the interests, welfare, or expectations of others [16,34]. Earlier, Jones [15] conceptualized situational characteristics of a moral issue as being an important aspect of an individual's ethical decision-making process that he labels as "moral intensity". Empirical studies have found support for this view of situational characteristics of a moral issue as influencing an individual's ethical perceptions, intentions and actions $[35,36]$ One of the most frequently studied characteristics of moral intensity is magnitude of consequences which is defined as the "sum of the harms (or benefits) done to victims (or beneficiaries) of the moral act in question" [15]. In several studies, magnitude of consequences has been found to relate to individual judgments and actions $[37,38]$ issues with greater magnitude of consequences are more salient and these issues stand out from their backgrounds because their effects are more extreme. Chia \& Mee [39] found that issues that have larger magnitudes of consequences are more frequently responded to as moral issues than are issues that have smaller magnitudes of consequences. While magnitude is a well-known situational influence on ethical decision-making, we focus on an additional issue-related factor not proposed by Jones [15]. We examine the situational factor of severity (blatant versus subtle) of the ethical violation as being an influential determinant of ethical responses. Ethical violations that are blatant in nature will elicit 
different ethical responses than ethical dilemmas that are more subtle in nature. We argue that blatant ethical violations, in which an individual can clearly perceive the wrongdoings, will elicit a more constructive response. On the other hand, dilemmas that are more subtle in nature will be more ambiguous and the wrongdoing will not be readily apparent thereby influencing an individual's ability to recognize the ethical components of issues. Thus, subtle violations within the situation provide a critical framing for ethical problems that are likely to produce destructive response to ethical violations $[40,41]$.

\section{Contextual factors that impact responses to ethical violations}

In addition to examining situational factors, we explore the impact of contextual factors to better understand how individuals respond to ethical violations. We examine two aspects of context, rule-based and gender-based. In order to perform effectively, leaders need to learn and adhere to both explicit ethical codes and more subtle organizational norms and beliefs surrounding appropriate versus inappropriate behavior [18]. Researchers note the importance of examining how context impacts individuals' abilities to detect rule violations [42]. In the specific context of college athletics, researchers have provided numerous examples where compliance officers have to interpret the rules and how they follow the rules when faced with an ambiguous situation [3]. By adhering to the rules and interpreting the context in which these rules are applied, leaders must balance these different aspects of the context in making ethical judgements and decisions.

Thus, it makes sense that when leaders are faced with explicit rule-based ethical violation, the context signals that constructive responses are appropriate. While rules shape some of the context in which these decisions are made, there are other contextual factors that we should consider. The increase of women in leadership roles provides a unique contextual factor where their experiences can impact or shape the interpretation of behaviors and their consequences [43]. Having diverse groups within the workplace can create dynamics that are experienced differently based on factors such gender, race, sexuality, social class, culture, etc. [44]. This is highlighted by the extensive work on microaggressions in the workplace where behavior and its intent are experienced, judged and responded to differently based on social group status [45]. Thus, we examine gender-based violations as context for the valuation of ethical violations by female leaders. Though organizations may provide rules that explicitly lay out the policies and procedures regarding ethics, we argue that members of historically disadvantaged groups will respond differently if these violations are related to their social group membership. When the ethical violations are based on the non-adherence of explicit rules, it may be easier for individuals to act in a constructive manner and resolve the situation. On the other hand, we argue that the contextual impact of gender-based violations will yield a different response given that women as leaders will experience and react to these violations from their unique experience (e.g., destructive). In addition to examining the situation and contextual factors that influence responses to ethical violations, our research employs a unique model for measuring these responses. The current research uses the investment model to capture different responses to ethical violations from a relational perspective. We argue that while extant models have emphasized cognitive aspects of decision making, we need to include relational factors. Building on Hirschman's [46] framework of responses to organizational decline, Rusbult suggested a typology based on the combination of constructive versus destructive responses contrasted by passive versus active responses.

This yields 4 unique response options:

1. Exit refers to leaving an organization by quitting, transferring, searching for a different job or thinking about quitting (destructive, active).

2. Voice describes actively and constructively trying to improve conditions through discussing problems with a supervisor or co-workers, taking action to solve problems, suggesting solutions, seeking help from an outside agency like a union, or whistleblowing (constructive, active).

3. Loyalty means passively but optimistically waiting for conditions to improve-giving public and private support to the organization, waiting and hoping for improvement, or practicing good citizenship (constructive, passive).

4. Neglect refers to passively allowing conditions to deteriorate through reduced interest or effort, chronic lateness or absences, using company time for personal business, or increased error rate (destructive, passive).

The four response options (exit, voice, loyalty, and neglect) differ along two dimensions of constructive versus destructive and active versus passive. Constructive responses are ones in which individuals strive to revive or maintain satisfactory conditions. Voice and loyalty are the two response categories that fall under the constructive dimension. On the other hand, exit and neglect fall under the destructive dimension [47]. In the second dimension of activity versus passivity, exit and voice are active reactions in which individuals directly attempt to deal with dissatisfying conditions at work, whereas loyalty and neglect reflect more passive attempts to deal with the problem [8]. Although Rusbult's typology has been primarily used in categorizing employees' responses to job dissatisfaction, we wish to extend this typology to how individuals respond to ethical violations with special attention on the two dimensions of destructive/constructive and passive/ active. When individuals face an ethical violation, they can simply ignore the unethical act and do nothing (neglect); report it to the proper person or unit (voice); share it with a friend or a superior but not report it (loyalty), and finally consider leaving the job but not report it (exit). In our study, we specifically address the what situational and contextual factors lead some leaders to react constructively (voice and loyalty) and others to react destructively (exit and neglect) to ethical violations. These relational responses are especially relevant as we examine women leaders and their responses to ethical violations in collegiate athletics. While college athletics have been praised for their efforts in promoting the competitive spirit, they have also been viewed negatively for issues 
such as cheating, violating the rules stated by governing bodies, and undermining the principles of higher education [13]. Sport leaders work in a highly relational and complex setting where how they resolve ethical violations is influenced by rules, regulations and codes of conduct set by the educational organization $[10,48,49]$. However, when faced with ethical violations, sport leaders must not only examine the organizational factors, but also consider how educational values and mission are impacted [8]. The increased visibility of these decisions is heightened by the increase in the number of institutions being penalized for rules violations [50]. It is important to include both situational and contextual factors based on a relational approach to better understand how leaders respond to ethical violations within a sports context [51]. Thus, we expect that situational factors (blatant versus subtle) and contextual factors (rule-based versus gender-based) will impact leaders' responses to ethical violations based on the relational perspective (constructive versus destructive and active versus passive).

\section{Methods}

We use vignettes to depict various ethical violations. Vignettes are useful because they enable researchers to compare responses in a standardized context which is laden with a large amount of background information [39,52,53]. Vignettes have been used frequently in business ethics research [54,55].

\section{Participants}

Data were collected using self-administered questionnaires distributed with the help of personnel department in a large sized university in the United States. Responses were obtained from 100 female athletic administrators. Our sample predominantly consisted of Caucasian women (95\% Caucasian). Six percent of the respondents were between 18-24 years old, $46 \%$ between $25-34$ years, $20 \%$ between $35-44$ years, $21 \%$ between $45-54$ years, and $7 \%$ between 55 years and above. Sixty four percent of the respondents had a master's degree or higher. Most of the respondents had either 1-5 years (34\%) or 6-10 years (33\%) of experience in athletic leadership.

\section{Measures}

Eight vignettes were constructed based on the severity and context of ethical issues. The ethical dilemmas covered in the vignettes and the corresponding severity and content of the ethical issues are summarized in Table 1. Each category of ethical issuesblatant severity, subtle severity, rule-based violations and genderbased violations-comprised a total of eight vignettes that were presented in a random order to participants. After reading each scenario, respondents were asked to select one of the following responses which best captures how they would react in this situation based on Rusbult's investment model:

1. I would not tell anyone and would not report it. (Neglect)

2. I would tell a friend or my superior, but not report it. (Loyalty)

3. I would consider leaving my job, but not report it. (Exit)

4. I would report it to the proper person/unit. (Loyalty)

Table 1: Summary of ethical violation vignettes.

\begin{tabular}{|c|c|c|}
\hline $\begin{array}{c}\text { Severity of } \\
\text { violation }\end{array}$ & $\begin{array}{l}\text { Context of } \\
\text { violation }\end{array}$ & Summary of dilemma \\
\hline Blatant & $\begin{array}{l}\text { Rule-based } \\
\text { violations }\end{array}$ & $\begin{array}{l}\text { Consider this situation. You are the senior associate athletic director. It is your first week at a new university. It has } \\
\text { been brought to your attention that the women's softball team has been disadvantaged compared to the baseball team } \\
\text { at your new university. Reports indicate that the facilities (e.g., lack of an electronic scoreboard, dugouts, a regulation } \\
\text { backstop) and practice times are not comparable. After investigating the situation, you find that this has been the } \\
\text { case for over two years. Which one would most likely be your response? }\end{array}$ \\
\hline Subtle & $\begin{array}{l}\text { Rule-based } \\
\text { violations }\end{array}$ & $\begin{array}{l}\text { Consider this situation. You are the entry-level marketing assistant. You go to your boss, director of sports marketing, } \\
\text { with several ideas regarding promotions and community exposure for the football team. He/she tells you that your } \\
\text { ideas are good, but there is no way to implement them for the upcoming season. The next week there is a meeting } \\
\text { with you, your boss and a few executive staff members. During the meeting, one of the assistant athletic directors } \\
\text { asks your boss what he/she has planned for promotions and community exposure for the upcoming football season. } \\
\text { Three out of the five ideas that he/she answers are your ideas that you had approached him/her about the previous } \\
\text { week. Which one of the following would most likely be your reaction? }\end{array}$ \\
\hline Blatant & $\begin{array}{l}\text { Gender-based } \\
\text { violations }\end{array}$ & $\begin{array}{l}\text { Consider this situation. You are the ticket manager. A staff member leaves the athletic department and the position } \\
\text { of assistant ticket manager for men's basketball becomes vacant. The assistant athletic director of ticketing has } \\
\text { narrowed down the choices to three potential candidates (two men and one woman) for the given position. Current- } \\
\text { ly, the ticket office has a 75:25 men to women ratio. You have the unique opportunity to take each candidate out to } \\
\text { lunch, do an informal interview and review their qualifications. Clearly, after interviewing all three candidates, the } \\
\text { woman was the most qualified candidate by the standards your boss proposed, the assistant athletic director of tick- } \\
\text { eting. The next week your boss tells you that he hired one of the two males. Which one of the following would most } \\
\text { likely be your reaction? }\end{array}$ \\
\hline
\end{tabular}




\begin{tabular}{|c|c|c|}
\hline Subtle & $\begin{array}{l}\text { Gender-based } \\
\text { violations }\end{array}$ & $\begin{array}{l}\text { Consider this situation. You are the director of compliance. One of the graduate assistants confides in you that she } \\
\text { has experienced some resentment within her department. She thinks that it is because she is a woman. She tells you } \\
\text { that she has heard several remarks over the last couple months, which make her feel uncomfortable and self-con- } \\
\text { scious about her work. She tells you not to say anything, but just wanted your advice on dealing with the situation. } \\
\text { Which one of the following would most likely be your reaction? }\end{array}$ \\
\hline Subtle & $\begin{array}{l}\text { Rule-based } \\
\text { violations }\end{array}$ & $\begin{array}{l}\text { Consider this situation. You are the director of development and fundraising. At a local alumni chapter meeting, one } \\
\text { of the university's student-athletes is speaking about the progress in their respective sport that season. There was } \\
\text { no dinner served at the meeting and the student-athlete did not eat all day. After the student-athlete presents and is } \\
\text { ready to leave, one of the alumni donors gives the student-athlete } \$ 20 \text { for gas and food. Which one of the following } \\
\text { would most likely be your reaction? }\end{array}$ \\
\hline Subtle & $\begin{array}{l}\text { Gender-based } \\
\text { violations }\end{array}$ & $\begin{array}{l}\text { Consider this situation. You are the assistant to the associate athletic director. Your boss asks you to attend a meeting } \\
\text { with some of the executive staff members to discuss parking for the upcoming men's and women's basketball games. } \\
\text { This is your first meeting with this group and you will be the only woman in attendance. The meeting begins and } \\
\text { you quickly begin to feel uncomfortable because of the inappropriate language used among the men conducting the } \\
\text { meeting. Which one of the following would most likely be your reaction? }\end{array}$ \\
\hline Blatant & $\begin{array}{l}\text { Gender-based } \\
\text { violations }\end{array}$ & $\begin{array}{l}\text { Consider this situation. You are the assistant athletic director responsible for football operations. Your school's star } \\
\text { wide receiver has been arrested for allegedly assaulting a young woman outside a local nightclub a week before the } \\
\text { football season is scheduled to begin. Police reports indicate that the story given by the wide receiver is more credi- } \\
\text { ble than that of the woman. You and the football coach are the first to find out about the incident in your department. } \\
\text { Which one of the following would most likely be your reaction? }\end{array}$ \\
\hline Blatant & $\begin{array}{l}\text { Rule-based } \\
\text { violations }\end{array}$ & $\begin{array}{l}\text { Consider this situation. You are the director of athletics. You have recently discovered that your football coach has } \\
\text { participated in an NCAA men's basketball gambling pool. After confronting him, he informs you that an athletic } \\
\text { administrator notified him that it was permissible to participate in the pool. Which one of the following would most } \\
\text { likely be your reaction? }\end{array}$ \\
\hline
\end{tabular}

Since voice and loyalty are constructive responses to resolve situations, we aggregated the scores of these two categories to have an overall constructive response score for the respondents. Similarly, we aggregated the neglect and exit responses scores to have an overall destructive response score for the respondents. We also combined responses of exit and voice as a measure of active response and neglect and loyalty as a measure of passive response. We also included a measure of ethical attitudes using questions that assessed respondents' perceptions of the degree of importance given by their organizations to ethical violations and their understanding of the concept of ethical within the organizations. These statements were based on discussions with college athletic administrators. We used six statements each having responses on a 5-point scale (1-strongly disagree and 5-strongly agree). All the statements of the ethical attitudes scale are in Table 2. The factor analysis results confirmed the loading of all the items on one scale. Cronbach alpha for the scale is 87 .

Table 2: Ethical attitudes scale.

\section{Ethical Attitudes Scale}

Items in scale. Please indicate your agreement with the statements on the following scale:

1-Strongly Disagree, 2-Disagree, 3-Neither Agree nor Disagree, 4-Agree, 5-Strongly Agree

1. The operations of your athletic department are ethical.

2. Our senior staff will not tolerate unethical behavior.

3. Ethical behavior in your athletic department is more important than winning.

4. Ethical behavior in your athletic department is more important than revenue.

5. If I observed unethical behavior in this athletic department, I know how to report it.

6. I have never felt "pressure" from a fellow athletic administrator or university officials to violate ethical standards or behave in an unethical manner.

\section{Result}

The mean, standard deviation, and intercorrelations among the variables in the study are shown in Table 3. The correlations between the variables demonstrate that two of the control variables, age and tenure were significantly related to ethical attitudes. We used one-way directional t-tests to assess the difference in responses to ethical violations based on severity and context of the ethical dilemmas. The results are presented in Table 4 . We found that constructive responses (voice and loyalty) were greater for blatant violations than subtle violations $(\mathrm{t}=53.25, \mathrm{p}<.01)$. T-test results indicate that destructive responses (exit and neglect) were greater for subtle violations than blatant violations $2 \mathrm{~b}(\mathrm{t}=4.56$, $\mathrm{p}<.01$ ). Constructive responses (voice and loyalty) were greater for rule-based ethical violations than gender-based ethical violations was also supported $(t=4.52, \mathrm{p}<.01)$. Finally, destructive responses (exit and neglect) were greater for gender-based ethical violations than rule-based violations $(\mathrm{t}=4.52, \mathrm{p}<.01)$. Interestingly, there were no significant differences based on active versus passive responses 
to ethical violations. Lastly, we performed regression analysis using the measure of ethical attitudes as the independent variable and its effect on the four ethical dilemmas. We find that positive endorsement of ethical values predicted constructive responses (voice and loyalty) to ethical violations (model 3: $\beta=.02, p<.05$ ) but only for rule-based vignettes. We did not find an association between ethical attitudes and destructive responses to ethical violations across any of the vignettes.

Table 3: Descriptive statistics and correlations.

\begin{tabular}{|c|c|c|c|c|c|c|c|c|c|c|c|c|c|c|}
\hline No. & Variables & Mean & s.d. & 1 & 2 & 3 & 4 & 5 & 6 & 7 & 8 & 9 & 10 & 11 \\
\hline 1 & Age & 2.77 & 1.07 & 1 & & & & & & & & & & \\
\hline 2 & Education & 5.29 & 1.13 & $.22^{*}$ & 1 & & & & & & & & & \\
\hline 3 & Tenure & 2.85 & 1.01 & $.66^{* *}$ & $.33^{* *}$ & 1 & & & & & & & & \\
\hline 4 & $\begin{array}{l}\text { Ethical Atti- } \\
\text { tudes }\end{array}$ & 24.12 & 4.47 & $.20^{*}$ & 0.09 & $.24^{*}$ & 1 & & & & & & & \\
\hline 5 & $\begin{array}{c}\text { Overall } \\
\text { Constructive } \\
\text { Response } \\
\text { (Blatant) }\end{array}$ & 3.78 & 0.47 & -0.01 & 0.14 & 0.12 & 0.19 & 1 & & & & & & \\
\hline 6 & $\begin{array}{l}\text { Overall } \\
\text { Destructive } \\
\text { Response } \\
\text { (Blatant) }\end{array}$ & 0.22 & 0.47 & 0.01 & -0.14 & -0.12 & -0.19 & $-1.00^{* *}$ & 1 & & & & & \\
\hline 7 & $\begin{array}{c}\text { Overall } \\
\text { Constructive } \\
\text { Response } \\
\text { (Subtle) }\end{array}$ & 3.34 & 0.8 & 0.01 & 0.13 & 0.07 & 0.18 & $.33^{* *}$ & $-.33^{* *}$ & 1 & & & & \\
\hline 8 & $\begin{array}{c}\text { Overall } \\
\text { Destructive } \\
\text { Response } \\
\text { (Subtle) }\end{array}$ & 0.66 & 0.8 & -0.01 & -0.13 & -7 & -0.18 & $-.33^{* *}$ & $.33^{* *}$ & $-1.00^{* *}$ & 1 & & & \\
\hline 9 & $\begin{array}{c}\text { Overall } \\
\text { Constructive } \\
\text { Response } \\
\text { (Rule-Based) }\end{array}$ & 3.78 & 0.51 & -0.17 & $.21^{*}$ & 0.08 & 0.19 & $.43^{* *}$ & $-.43^{* *}$ & $.53^{* *}$ & $-.53^{* *}$ & 1 & & \\
\hline 10 & $\begin{array}{c}\text { Overall } \\
\text { Destructive } \\
\text { Response } \\
\text { (Rule-Based) }\end{array}$ & 0.22 & 0.51 & 0.17 & $-.21^{*}$ & -0.08 & -0.19 & $-.43^{* *}$ & $.43^{* *}$ & $-.53^{* *}$ & $.53^{* *}$ & $-1.00^{* *}$ & 1 & \\
\hline 11 & $\begin{array}{c}\text { Overall } \\
\text { Constructive } \\
\text { Response (Di- } \\
\text { versity-Based) }\end{array}$ & 3.33 & 0.88 & 0.06 & 0.07 & 0.02 & 0.15 & $.59^{* *}$ & $-.59^{* *}$ & $.82^{* *}$ & $-.82^{* *}$ & 0.17 & -0.17 & 1 \\
\hline 12 & $\begin{array}{c}\text { Overall } \\
\text { Destructive } \\
\text { Response (Di- } \\
\text { versity-Based) }\end{array}$ & 0.67 & 0.88 & -0.06 & -0.07 & -0.02 & -0.15 & $-.59^{* *}$ & $.59^{* *}$ & $-.82^{* *}$ & $.82^{* *}$ & -0.17 & 0.17 & $-1.00^{* *}$ \\
\hline
\end{tabular}


Table 4: Analysis of responses to ethical violation vignettes.

\begin{tabular}{|c|c|c|c|c|c|}
\hline \multicolumn{2}{|c|}{ Severity of Ethical Dilemma } & \multicolumn{3}{|c|}{ Subtle } \\
\hline & \multicolumn{2}{|c|}{ Blatant } & M SD & t-Value \\
\cline { 2 - 6 } & M & SD & & \\
\hline Responses to ethical dilemma & & & & \\
\hline Overall Constructive Response Score (voice and loyalty) & 3.78 & 0.46 & 0.22 & 0.46 & $53.25^{* *}$ \\
\hline Overall Destructive Response Score (neglect and exit) & 0.22 & 0.46 & 0.67 & 0.84 & $4.56^{* *}$ \\
\hline
\end{tabular}

$* * \mathrm{p}<.01$

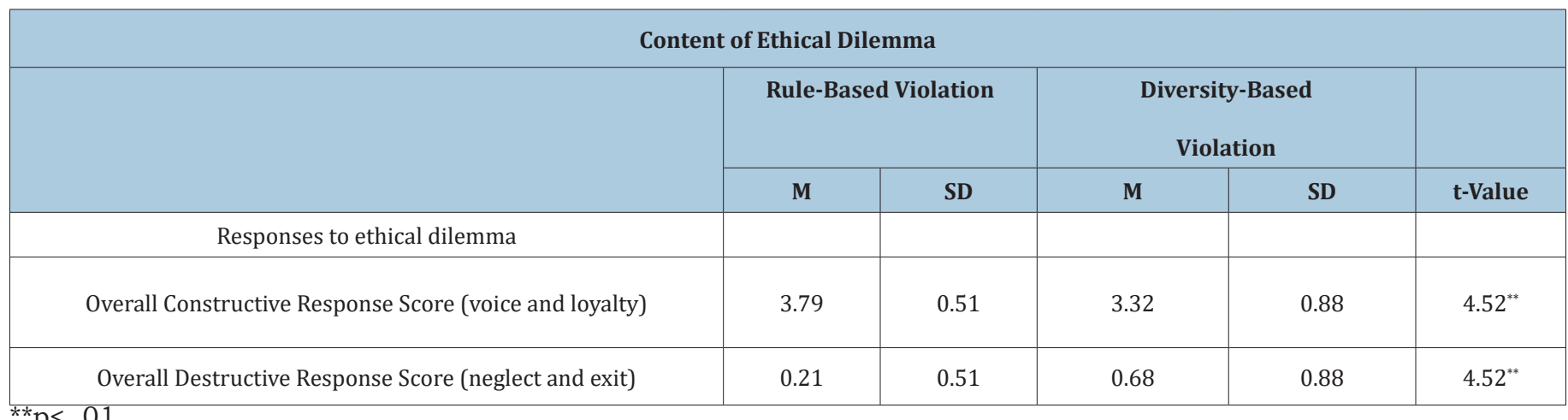

\section{Discussion and Conclusion}

The purpose of this study was to examine the role of situational and contextual factors on female athletic leaders' responses to ethical violations. We examine the influence of blatant versus subtle violation and rules-based versus gender-based violations. Using Rusbult's typology of exit, voice, loyalty and neglect responses [1], we attempt to understand how these factors influences athletic leaders' responses to ethical violations (constructive/destructive or active/passive). Overall, the study found that that ethical responses were characterized by constructive (voice and loyalty) more for blatant than subtle violations. In addition, destructive responses (exit and neglect) were greater for subtle than blatant violations. Interestingly, destructive responses (exit and neglect) were greater for gender-based violations than rule-based violations. Ethical attitudes were positively associated with constructive responses (voice and loyalty) for rule-based ethical violations but not for gender-based violations. Our findings make a contribution to the existing literature by including both situational and contextual factors along with a relational perspective for capturing responses to ethical violations. We see our findings as adding to the existing work that uses the investment model (exit, voice, loyalty, neglect) to capture individuals' responses to unfavorable work environments by extending it to leaders' reactions to ethical violations. Our findings that constructive responses (voice and loyalty) are chosen more frequently for blatant than subtle violations and that destructive responses (exit and neglect) were chosen more frequently for subtle than blatant violations could be viewed from the theoretical perspective of reactions to a psychological contract breach. Recent work links psychological contract breach to employee voice [56], intent to quit or exit [57], employees' unethical behavior or neglect [58], and employee silence or loyalty [59]. Thus, responses to ethical violations by our female athletic administrators could be conceptualized as their reactions to a perceived breach in their psychological contracts as leaders or representatives of the organization.

Our results showed that destructive responses (exitand neglect) were greater for gender-based violations than rule-based violations. Recent work by Sexsmith (2016) on migrant farm workers on New York dairies found that exit or voice can be constrained by structural forces (e.g., weak employment protection, fear of retaliation) for some employees. For gender-based violations, this may suggest that responses that move from being individual to collective may be more effective for these women leaders. This would suggest linking reactions to ethical violations to the research on collective action and social activism. The option of collective action could also be seen as a response to the accumulation of psychological contract breaches over time which has been shown to be positively associated with increased feelings of violation and counterproductive workplace behavior [60]. Integrating the investment model which focuses on individual-level responses to research on collective action would be an opportunity for future research on responses to ethical violations in organizational settings.

Leaders work in complex environments where they constantly face ethical challenges in performing their day-to-day responsibilities. Some of the ethical dilemmas athletic leaders confront include interpreting rules and regulations, adhering to codes of ethics, managing role conflicts, and meeting organizational goals and objective [3]. To perform effectively, sport administrators need to strike a balance between following the rules laid down by 
the organization and their own moral beliefs. In order to capture the complexity of the environment in which sport administrators work, one must pay attention to both the situational and contextual factors that our findings show impact responses to ethical violations. In rule-based violations, our leaders appeared to draw on their knowledge of formal rules and elect a more constructive response, such as addressing the issue by reporting it to the proper person or unit. However, our female leaders responded to gender-based violations in a different matter than rules-based violations. Their responses were more destructive falling into categories of exit and neglect. This finding is consistent with other research that shows the negative impact of hostile work environments for women on issues such as retention, satisfaction and engagement [24].

One limitation of this study is that the use of vignettes to assess responses to ethical violations may limit generalizability. Since respondents indicate the action they may take for hypothetical vignettes, we cannot be certain that their response will relate to their actual behavior in real situations [24,34]. Despite these limitations, vignettes have been used frequently in ethics research because they enable the context to be laden with rich background information [39]. Another limitation of our study is that our sample consisted only of women leaders. While a lot of research has been done to examine the effects of gender on ethical behavior, the findings have been inconclusive. While some studies have found females to be more ethical [57], other studies have found no gender differences [58]. By including males in our sample, we would have been able to examine gender differences in responses to ethical violations. Despite these limitations, our study offers new insights by providing a relational framework to assess responses to ethical violations. Extant ethical decision-making models have predominantly focused on cognitive aspects to assess ethical rule violations and have largely ignored the role of relational factors. We argue that it is important to view ethical violations from a relational perspective as individuals are closely tied to their surrounding context when they are faced with ethical situations. Overall, we find that female leaders' responses to ethical violations vary based on these key situational and contextual factors.

\section{Acknowledgement}

The authors wish to thank Stephanie Menio and Anushri Rawat for their invaluable assistance with this research. Funding for this research was provided by the David Berg Center for Ethics and Leadership at the University of Pittsburgh.

\section{References}

1. Rusbult CE, Zembrodt IM, Gunn LK (1982) Exit, voice, loyalty, and neglect: Responses to dissatisfaction in romantic involvements. Journal of Personality and Social Psychology 43(6): 1230-1242.

2. Coombs JR (1997) Practical reasoning: What is it? How do we enhance it? In: Laster JF, Thomas RG (Eds.), Thinking for ethical action in families and communities. American Association of Family and Consumer Sciences, Peoria, Illinois, pp. 1-16.

3. Kihl L (2007) Moral codes, moral tensions and hiding behind the rules: A snapshot of athletic administrators' practical morality. Sport Management Review 10(3): 279-305.

4. Wallace J (1996) Ethical norms, particular cases. Cornell University
Press, Ithaca, New York, USA.

5. Schwartz MS (2013) Developing and sustaining an ethical corporate culture: The core elements. Business Horizons 56(1): 39-50.

6. Tetlock PE (2002) Social functionalist framework for judgement and choice: Intuitive politicians, theologians and prosecutors. Psychology Review 109(3): 451-471.

7. Welch DD (1994) Conflicting agendas: Personal morality in institutional settings. The Pilgrim Press, Cleveland, Ohio, USA.

8. Farrell D, Rusbult C (1992) Exploring the exit, voice, loyalty, and neglect typology: The influence of job satisfaction, quality of alternatives, and investment size. Employee Responsibilities and Rights Journal 5(3): 201-217.

9. Dixon MA (2000) Do cheaters ever prosper? An exploratory investigation of the reasoning behind NCAA rule violations. Future Focus 21(2): 2834.

10. Simon RL (1991) Fair play: Sports, values, and society. Westview Press, San Francisco, USA.

11. Lumpkin A, Stoll SK, Beller JM (1994) Sport Ethics: Applications for Fair Play. Mosby, St. Louis, Missouri, USA.

12. Sivadas E, Kleiser SB, Kellaris J, Dahlstrom R (2003) Moral philosophy, ethical evaluations, and sales manager hiring intentions. Journal of Personal Selling \& Sales Management 23(1): 7-21.

13. Dixon MA, Turner BA, Pastore DL, Mahony DF (2003) Rule violations in intercollegiate athletics: A qualitative investigation utilizing an organizational justice framework. Journal of Academic Ethics 1(1): 5990.

14. Fleisher AA, Goff BL, Tollison RD (1992) The National Collegiate Athletic Association: A study in cartel behavior. University of Chicago Press, Chicago, USA.

15. Jones TM (1991) Ethical decision making by individuals in organizations: An issue-contingent model. Academy of Management Review 16(2): 366-395.

16. Rest JR (1986) Moral development: Advances in research and theory. Praeger, New York, USA.

17. Trevino LK (1986) Ethical decision making in organizations: A personsituation interactionist model. Academy of Management Review 11(3): 601-617.

18. Trevino LK, Weaver GR, Reynolds SJ (2006) Behavioral ethics in organizations: A Review. Journal of Management 32(6): 951-990.

19. Ford RC, Richardson WD (1994) Ethical decision making: A review of the empirical Literature. Journal of Business Ethics 13(3): 205-221.

20. 0 Fallon MJ, Butterfield KD (2005) A review of the empirical ethical decision-making literature: 1996-2003. Journal of Business Ethics 59(4): 375-413.

21. Cole BC, Smith DL (1996) Perceptions of business ethics: Students vs. business people. Journal of Business Ethics 15(8): 889-896.

22. Tse ACB, Au AKM (1997) Are New Zealand business students more unethical than non-business students? Journal of Business Ethics 16(4): 445-450.

23. Roozen I, Pelsmacker PD, Bostyn F (2001) The ethical dimensions of decision processes of employees. Journal of Business Ethics 33(2): 8799.

24. Weeks WA, Moore CW, McKinney JA, Longenecker JG (1999) The effects of gender and career stage on ethical judgment. Journal of Business Ethics 20(4): 301-313.

25. Schepers DH (2003) Machiavellianism, profit, and the dimensions of ethical judgment: A study of impact. Journal of Business Ethics 42(4): 339-352. 
26. Verbeke W, Uwerkerk C, Peelen E (1996) Exploring the contextual and individual factors on ethical decision making of salespeople. Journal of Business Ethics 15(11): 1175-1187.

27. McCuddy MK, Peery BL (1996) Selected individual differences and collegians ethical beliefs. Journal of Business Ethics 15(3): 261-272.

28. Kennedy JA, Kray LJ (2014) Who is willing to sacrifice ethical values for money and social status? Gender differences in reactions to ethical compromises. Social Psychological and Personality Science 5(1): 52-59.

29. Bartels LK, Harrick E, Martell K, Strickland D (1998) The relationship between ethical climate and ethical problems within human resource management. Journal of Business Ethics 17(7): 799-804.

30. Weber J, Kurke LB, Pentico DW (2003) Why do employees steal? Assessing differences in ethical and unethical employee behavior using ethical work climates. Business \& Society 42(3): 359-380.

31. Schwartz MS (2001) The nature of the relationship between corporate codes of ethics and behavior. Journal of Business Ethics 32(3): 247-262.

32. Greenberg J (2002) Who stole the money and when? Individual and situational determinants of employee theft. Organizational Behavior and Human Decision Processes 89(1): 985-1003.

33. Oz E (2001) Organizational commitment and ethical behavior: An empirical study of information system professionals. Journal of Business Ethics 34(2): 137-142.

34. Davis MA, Johnson NB, Ohmer DG (1998) Issue-contingent effects on ethical decision making: A cross-cultural comparison. Journal of Business Ethics 17(4): 373-389.

35. Singhapakdi A, Vitell SJ, Franke GR (1999) Antecedents, consequences, and mediating effects of perceived moral intensity and personal moral philosophies. The Journal of Academy of Marketing Science 27(1): 1936.

36. Rallapalli KC, Vitell SJ, Barnes JH (1998) The influence of norms on ethical judgments and intentions: An empirical study of marketing professionals. Journal of Business Research 43(3): 157-168.

37. Weber J (1996) Influences upon managerial moral decision making: Nature of the harm and magnitude of consequences. Human Relations 49(1): 1-22.

38. Butterfield KD, Trevino LK, Weaver GR (2000) Moral awareness in business organizations: Influences of issue-related and social context factors. Human Relations 53(7): 981-1018

39. Chia A, Mee LS (2000) The effects of issue characteristics on the recognition of moral Issues. Journal of Business Ethics 27(3): 255-269.

40. Marshall B, Dewe P (1997) An investigation of the components of moral intensity. Journal of Business Ethics 16(5): 521-530.

41. Messick DM, Bazerman MH (1996) Ethical leadership and the psychology of decision making. Sloan Management Review 37(2): 9-22.

42. Wasieleski DM, Hayibor S (2008) Breaking the rules: Examining the facilitation effects of moral intensity characteristics on the recognition of rule violations. Journal of Business Ethics 78(1-2): 275-289.

43. Gilbert JA, Stead B, Ivancevich JM (1999) Diversity management: A new organizational paradigm. Journal of Business Ethics 21(1): 61-76.
44. McDaniel C, Schoeps N, Lincourt J (2001) Organizational ethics: Perceptions of employees by gender. Journal of Business Ethics 33(3): 245-256.

45. Sue DW (2010) Microaggressions in Everyday Life: Race, gender, and sexual Orientation. Wiley, Hoboken, New Jersey, USA.

46. Hirschman A (1970) Exit, voice, and loyalty: Responses to decline in firms, organizations, and states. Harvard University Press, Cambridge, Massachusetts, USA.

47. Rusbult C, Farrell D, Rogers G, Mainous A (1988) Impact of exchange variables on exit, voice, loyalty, and neglect: An integrative model of responses to declining job satisfaction. Academy of Management Journal 31(3): 599-627.

48. Gough R (1994) NCAA policy's strangling effect on ethics. For the Record 3-5.

49. Michael ML (2006) Business ethics: Law of rules. Business Ethics Quarterly 16(4): 475-504.

50. Mahony DF, Fink JS, Pastore DL (1999) Ethics in intercollegiate athletics: An examination of NCAA violations and penalties-1952-1997. Professional Ethics 7(2): 53-74.

51. De Waegeneer E, Van De Sompele J, Willem A (2016) Ethical codes in sports organizations: Classification framework, content analysis, and the influence of content on code effectiveness. Journal of Business Ethics 136(3): 587-598.

52. Alexander CS, Becker HJ (1978) The use of vignettes in survey research. Public Opinion Quarterly 42(1): 93-104.

53. Hunt SD, Vitell SJ (1986) A general theory of marketing ethics. Journal of Macromarketing 6(1): 5-16.

54. Fritzsche DJ, Becker H (1984) Linking management behavior to ethical philosophy: An empirical investigation. Academy of Management Journal 27(1): 166-175.

55. Robertson DC, Anderson E (1993) Control system and task environment effects on ethical judgment: An exploratory study of industrial salespeople. Organization Science 4(4): 617-644.

56. Ajzen I, Fishbein M (1980) Understanding attitudes and predicting social behavior. Prentice-Hall, Englewood Cliffs, New Jersey, USA.

57. Kidwell JM, Stevens RE, Bethke AL (1987) Differences in ethical perceptions between male and female managers: Myth or reality? Journal of Business Ethics 6(6): 489-493.

58. McNichols CW, Zimmerer TW (1985) Situational ethics: An empirical study of differentiators of student attitudes. Journal of Business Ethics 4(3): 175-180.

59. Serwinek PJ (1992) Demographic \& related differences in ethical views among small Businesses. Journal of Business Ethics 11(7): 555-566.

60. Treviño LK, Nelson K (2004) Managing business ethics: Straight talk about how to do it right ( $3^{\text {rd }}$ edn), John Wiley \& Sons, Inc., New York, USA. 